\title{
Insights from Six Women on Their Personal Journeys to Becoming Deans of Agriculture: A Qualitative Study
}

\author{
Sarah Kleihauer \\ Agricultural Science Instructor \\ Wilson Central High School \\ Carrie Ann Stephens \\ Associate Professor \\ University of Tennessee \\ Knoxville, TN \\ William E. Hart \\ Associate Professor \\ University of Tennessee \\ Knoxville, TN
}

\begin{abstract}
Understanding one's personal journey provides for effective learning, growth, and development (Madsen, 2010). Reflection on the influences and experiences of successful women leaders is essential to understanding the factors that have enabled them to obtain and sustain leadership positions in nontraditional career fields. The purpose of this qualitative study was to conceptualize and describe the personal journeys of women who became deans of agriculture. The central research question was, "Describe your personal journey to becoming a dean of agriculture?" Six women deans of agriculture were interviewed and observed in an attempt to recognize the impact their personal journeys have had in developing their leadership styles and sustaining their leadership role. Conclusions were (a) they were first born children, (b) influenced by parental qualities and spousal support, and (c) mentors recognized their gifts and talents and encouraged them to pursue advanced degrees and leadership positions.
\end{abstract}

\section{Introduction and Theoretical Framework}

Understanding one's own personal journey provides for effective learning, growth, and development of self (Madsen, 2010). Reflection on the influences and experiences of successful women leaders is essential to understanding the factors 
that have enabled them to obtain and sustain leadership positions in nontraditional career fields. Bennis (1989) believed that in order for one to pass on their insight and perceptions of their experiences, they must fully understand and recognize the true value of the experience. He noted:

There are lessons in everything, and if you are fully deployed, you will learn most of them. Experiences are not truly yours until you think about them, analyze them, examine them, question them, reflect on them, and finally understand them. The point, once again, is to use your experiences rather than being used by them, to be the designer, not the design, so that experiences empower rather than imprison. (p. 98)

If one is to examine the true value of her experiences, a women's development and journey (e.g., culture, traditions, religion, values, backgrounds, education, work-family issues, self-concept, gender barriers, expectations, previous opportunities, perceived future opportunities) must be reflected upon and understood (Madsen, 2007). Madsen suggested that "understanding the influences, backgrounds, and career paths of women who have succeeded in obtaining and maintaining powerful positions of influence within higher education is essential in deepening and broadening our understanding of leadership development as a whole within higher education" (p. 184). Therefore, to understand this phenomenon, one must begin with exploring her childhood which is in essence the beginning of her journey.

Hennig and Jardim (1977) recognized childhood as being a significant period in an individual's development. Cooke (2004) agreed childhood relationships, developmental activities, and experiences (including hardships and times of pain) come together to create each human being. Sulloway (1996) maintained that "childhood and the family are central to the story of human behavior because they provide the immediate casual context for these developmental scenarios" (p. 118). Furthermore, "a person's inner sense of authority will be developed during childhood in the system of family relations, when the parents express their expectations, ideas, and emotions to their child" (Lorenzen, 1996, p. 26).

Parental interactions and expectations, however, differ according to the child's birth order. According to Ernst and Angst (1983), first born children experience more parental involvement, specifically verbal stimulation and strict parenting, than later born children. Falbo (1981) argued that a combination of positive parental attention and high parental expectations lead first born children to setting higher standards for themselves. As a result, first born children developed higher education aspirations and a higher degree of achievement motivation than later born children. Additionally, first born children share a closer relationship with 
their parents and thus compare themselves to their parents whereas last born children compare themselves to their older siblings.

In addition to birth order, relationships within the immediate family circle are central to the effective development of an individual's feelings of success, competence, and confidence (Falbo, 1981; Hartman, 1999; Wells, 1998). Furthermore, women in nontraditional occupations have parents who are highly supportive of their daughter's career interests (Auster \& Auster, 1981). In addition, successful women leaders are primarily raised in homes that are occupied by two parents (Hennig \& Jardim, 1977; Keown \& Keown, 1982; Woo, 1985) who have contributed to their daughters' development, resulting in the enhancement of each woman's confidence, knowledge, and skills important for leadership (Madsen, 2007).

In addition to parental support, achievements and behavior of parents greatly influence the motivation and values of women (Madsen, 2007). Madsen determined the strong educational background and community commitment of mothers provided a powerful model for women. While most of the women saw their mothers as "loving, committed, and dedicated," almost all of them also saw their mothers as "influential, competent, strong, intelligent, and fun" (Madsen, 2007, p. 577). Similarly, Matz (2002) found that a mother's impact on their daughter's self-esteem and inspiration was greater than the father's.

In contrast, women emphasized characteristics such as respect, strength, high expectations, and protection when describing their fathers (Madsen, 2006). For the most part, the fathers considered it important to "teach their daughters, as well as provide encouragement, opportunities, and education for them to become selfsufficient" (Madsen, 2006, p. 577). Hennig and Jardim (1977) and Astin and Leland (1991) also reported fathers had a stronger influence on the development, aspirations, and educational goals of their daughters. Hennig and Jardim (1977) noted that women were "taught, encouraged and supported by fathers, who expected them to aspire to and prepare for a career" (p. 118). Overall, women believe both parents are influential but that mothers have a stronger influence (Madsen, 2006).

The importance of parental relationships and influence to the development of women leaders is well documented (Astin \& Leland, 1991; Cubillo \& Brown, 2003; Hennig \& Jardim, 1977; Madsen, 2007). In Madsen's (2007) study of university presidents, when asked to speak about the individuals who influenced them through their adolescent and college years, most mentioned their parents' "encouragement to learn, be educated, use their minds, and aspire for college" (p. 10). Parents and family, along with faculty members, academic leaders, friends and peers, and other mentors help to establish a supportive and challenging 
environment, both personally and academically, which is important for the career success of women (Hennig \& Jardim, 1977).

Madsen (2007) reported "all of the women had authority figures who saw their gifts and talents and demanded quality and rigor" (p. 10). Van Velsor and Hughes (1990) and Wells (1998) determined that women have a remarkable capacity to learn from relationships and connections with others. Wells (1998) further noted women's self-images were not only founded in relationships they formed with others, but were also shaped by reinforcement and rewards of respected individuals. Good friends and peers are also excellent mentors to women as they progress in their careers (Madsen, 2007). These individuals acted as "sounding boards" (p. 113) and provided open and honest feedback, which was critical in gaining personal insight and strength.

Despite the support of family and mentors, however, women who pursue their career and leadership aspirations are confronted with choosing between family and career. McDonald (2004) argued the greatest challenge to women entrepreneurs is the difficulty of juggling a growing company and growing family. In Matz's (2002) study of women leaders, however, over $62 \%$ of the women sampled were married and almost 80 percent had children. Additionally, Matz found that over half of the women leaders felt their career never or only occasionally interfered with their personal lives. The women's success in keeping family and career separate may be explained by their spouses' willingness to share household labor and childcare. This domestic support had allowed these women to take on leadership positions in their careers while maintaining a household.

In a study of women administrators, Woo (1985) noted that women attributed their success to immense determination to have careers and the encouragement and support they received from their families. The majority of the women believed "their husbands' support had been a crucial factor in their careers" (Woo, 1985 , p. 287). Without that support, each woman believed she would have sacrificed her work before disbanding the marriage. Woo (1985) related women's need for encouragement and assistance to men in leadership roles who also rely heavily on their spouses for support. Indeed, the success of women and men in leadership roles is greatly influenced by the commitment of their spouses and families to their careers.

The effectiveness of an individual in a leadership role is also impacted by the style with which the individual leads; any difference is generally perceived as a product of gender and ultimately affects people's views of who should advance to a leadership position (Eagly \& Carli, 2004). As more women have begun occupying positions of leadership, numerous studies have been conducted to 
determine whether or not there are distinct differences in female and male leadership styles.

Eagly, Johannesen-Schmidt, and van Engen (2003) confirmed that women's typical leadership styles are more transformational than those of men. Female leaders are more focused on mentoring and empowering their followers to help develop their full potential and thus contribute more effectively to the organization (Eagly \& Carli, 2004). Conversely, male leaders appear to be more prone to exhibiting aspects of transactional leadership. This leadership style resembles traditional management practices, which consists of assigning a subordinate responsibility, rewarding them for meeting objectives, and correcting them for failing to meet objectives. Most managerial experts advocate the more feminine and androgynous skills of negotiation, cooperation, diplomacy, team building, and inspiring and nurturing others rather than distinctively masculine traits and skills. These feminine qualities parallel those that depict transformational leadership and are thus perceived as necessary attributes of effective leaders.

In examining a woman's journey to establish a leadership position, many factors seem to be common: strong family upbringing, excellent mentoring and spousal support. In a male-dominated field, such as agriculture, the question becomes do women have the same successful experiences? It is important to note that from our nation's earliest days, agriculture has held a crucial place in the American economy and culture. Today, the United States is looking to agricultural institutions for solutions to growing global concerns regarding economic uncertainty; natural resource and environmental issues; food security and sustainable agricultural practices; increasing foreign competition; and decreasing consumer understanding. While there are many complex factors that influence economic conditions and consumer awareness, it is clear that education in agriculture plays an important role in preparing farmers, researchers, educators, extension staff, members of agri-businesses, and others to make productive contributions (Food and Agriculture Organization of the United Nations, 1998). As a result, visionary and competent individuals are needed to drive higher education institutions to new levels of excellence and innovation and direct the future of the agricultural industry and our nation. However, Rubin (2004) argued that the development, attraction, and retention of extraordinary leaders are one of eight fundamental challenges facing higher education today.

Despite this documented concern about the preparation and retention of future educational leaders, there is little published research on the development of individuals who acquire leadership positions, such as college women deans. The role and leadership abilities of college deans are of particular importance in higher education because of the influence these leaders have on the direction and 
management of their institutions as well as the relationships they create and maintain with government officials, industry and community leaders, and their own faculty, staff, and students. Therefore, this article explored birth order, family influences, mentor experiences, and the spousal support system as each affected the leadership development and leadership success of woman deans.

\section{Purpose and Objectives}

The purpose of this qualitative study was to conceptualize and describe the personal journeys of women on their road to becoming deans of agriculture. The central research question addressed during the study was, "Describe your personal journey to becoming a dean of agriculture?" Each participant was asked probing or follow-up questions in an effort to indirectly guide their responses to provide the sought after information. Interview questions included (a) describe your family upbringing, (b) describe your immediate family, and (c) tell me about your road to becoming a dean of agriculture.

\section{Methods and Procedures}

In order to fully comprehend the experiences participants shared, the study was performed using the qualitative research method, which provided for a "complex, detailed understanding of the issue" (Creswell, 2007, p. 40). Gathering information from interviews, observations, documents, and pictures provided the researcher with a bank of data from which themes could be created, interpretations made, and a "rich, full picture of a research situation" painted (Wright, 2002/3, p. 8). A phenomenological approach was utilized in an attempt to gain entry into the conceptual world of study participants in order to understand how and what meaning they construct from their lived experiences (Bogden \& Biklen, 2007). Phenomenology allowed for the accurate interpretation and description of the meaning of the six women deans' experiences in sustaining their leadership roles in a predominantly male field.

The population for this study consisted of six women deans of agriculture in Land-Grant Institutions. Twenty-five women deans and associate deans were identified as possible study participants using the 2009 Directory of Deans and Directors of Academic Programs in Schools and Colleges of Agriculture (Association of Public and Land-grant Universities, 2009). While the researchers initially sought to engage women deans from each region of the Continental United States, women associate deans were asked to participate in regions where women deans were not accessible in an effort to maintain a representative sample of women who have all experienced the phenomenon of sustaining their leadership roles in a male-dominated field. Each dean was assigned a pseudonym 
to protect their identity and ensure the confidentiality of their statements. Heather and Kelly were interviewed from the northern region; in the southern region, Maggie was interviewed; Rachel and Laura were interviewed from the eastern region; and in the western region, Shelley was interviewed.

\section{Gaining Entry}

An Institutional Review Board Form B was completed and approval received by the University of Tennessee Research Compliance Services on April 27, 2009 to conduct the research. Each perspective participant was contacted by phone and email to secure authorization to participate in the study. Prior to conducting the interviews with each individual, an informed consent letter was signed and collected at the interview.

\section{Data Collection}

The methods employed to collect data in this study included one to two hour indepth interviews. The researcher's presence as a participant observer in the environments of each of the six women deans for two days was also utilized. During each field visit, the researcher recorded descriptive and reflective notes as she observed events and interactions in each dean's daily routine; which included meetings, workshops, classes, time with family at home. This enabled the researcher to gain an accurate account of the field as well as maintain the subjectivity of her understanding of each dean's experience. In addition, each dean participated in an audio-taped, semi-structured interview in which the researcher asked open-ended, non-leading questions (Creswell, 2007). The interviews focused on revealing the influences and experiences which helped to develop each woman. The interview protocol asked each participant to describe her family upbringing, her immediate family, and her road to becoming a dean of agriculture.

\section{Data Analysis}

The in-depth interviews were transcribed and analyzed along with the researcher's field notes. The data was examined using several methods, which included identifying significant statements and elements of meaning; creating textural and structural descriptions; and recognizing descriptions which revealed commonalities among the participants' experiences (Creswell, 2007). Emerging themes from all data were coded and sorted into specific categories by the researcher. 


\section{Validation Strategies}

Prior to launching the study, the researcher reflected on qualities she possessed which may impact her relationship with the environment and people in the study. First, the researcher holds a strong passion for agriculture as she grew up on a farm and is pursuing a degree in agriculture. The researcher's strong interest in this field may result in more focus on the selected women's impact in agriculture and how they have achieved their current status. Next, the researcher is female and possesses moderate feminist beliefs. She takes special interest in the stories of women who have overcome challenges in fields subjugated by males. This may influence the interview questions asked of participants pertaining to how they have achieved and sustained leadership positions in agriculture, a predominantly male field. Finally, the researcher has developed leadership characteristics and independence that have enabled her to take on a variety of leadership roles. Prior to commencing the study, the researcher believed women deans were independent and have assumed many leadership roles throughout their lives.

In an effort to keep a neutral viewpoint, the researcher reflected on her biases of the research topic and assumptions of the outcomes of the study prior to and during the research to maintain as impartial of a position as possible. The researcher personally reflected on each occasion of contact and communication with the participants. The researcher also structured the research question and probing questions in such a way that did not lead or guide the participant's responses in a predetermined direction.

In addition to the researcher's efforts to reduce the impact of bias on the data collected, several validation strategies were employed to document the "accuracy" and value of this phenomenological research study. Prolonged engagement in the field and the triangulation of data sources, methods, and investigators were techniques used to establish credibility (Creswell, 2007). From the researcher's observations, a thick description of each participant and their environment was constructed to help readers determine the transferability of the research. Dependability of the study was established through peer review by another researcher trained in qualitative analysis throughout the research process. Additionally, member checks of data, analyses, interpretations, and conclusions were conducted to confirm credibility of the study.

\section{Findings}

The results section is divided into four subsections: (a) birth order, (b) family influences, (c) mentor experiences, and (d) spousal support systems. 


\section{Birth Order}

Five of the six women deans in this study were first born children. The sixth dean was not the chronologically first born child, but was raised as the first born due to special circumstances. Being the first born child provides opportunities that younger siblings do not experience such as being a caretaker, taking on supervisory responsibilities and learning how to provide leadership at a young age. As stated by one of the deans:

Being the oldest, you become a parent of sorts. You take on care responsibilities, supervisory responsibilities, and ...I think you're just looked to fill in when your parents are not around. When mother and dad were out doing farm chores, I would watch after them. I think that you're just looked to sort of step up and fill in for the parents and many times I think that that's probably a role that older children take.

In addition to taking on supervisory responsibilities and leadership roles, first born children also assume parental duties, as note participant stated:

My father was killed when I was a freshman, so I think that there's another leadership role I sort of took on to help mother a little bit. You're the oldest and you're the most mature adult anyway that she could talk to so I just think that older siblings normally have a different kind of expectation and role than younger children do.

First born children are also subject to strict parental rules and high expectations. As one dean stated:

My father was the authoritarian, and he was the one that set the bar high, very demanding, and pushed....he was always one that if I got an A- I'd be saying, 'yeah!' and he'd be saying, 'Why isn't it an A?'”

\section{Family Influence}

Mothers and fathers of these women played a significant role in their accomplishment of becoming deans of agriculture. In general, the mothers were identified as the caregivers and the fathers were the authoritarians of the household. As expressed by one of the women deans, caregivers and authoritarians holistically develop individuals:

It was a team, it wasn't like they were working against one another, it was always that... my dad showed love in a very different way. I can remember getting upset sometimes and crying about something that happened and he would say 'Okay, that's enough, just suck it up and lets 
go.' And my mom would say, 'Oh, honey, I understand,' and pat me on the back. I needed both of these. I needed to hear 'Suck it up and move on,' but I also needed somebody to give me a hug and say, 'I understand.' They worked great as a team and so I'm really thankful for that.

While mothers were generally perceived as caregivers and fathers as authoritarians, each dean had a unique way of describing parents. Therefore, Table 1 and 2 contain descriptive words used by deans of agriculture about their mothers and fathers.

Table 1

Descriptive Words Used by Deans of Agriculture about their Mothers

\section{My Mother was/is...}

\begin{tabular}{lll}
\hline Homemaker & Strong & Adventurous \\
Educated & Determined & Brave \\
Independent & Stubborn & Generous \\
Quiet & Traditional & Not supportive of career \\
Bookish & Hospitable & Nurturing \\
Practical & Completely dependent & Disciplinarian \\
Nuts and Bolts & Housewife & Strong personality \\
Decision maker & Feminist & Creative \\
Inspiring & Extremely involved & Organized \\
& & \\
\hline
\end{tabular}

Table 2

Descriptive Words Used by Deans of Agriculture about their Fathers

\section{My Father was/is...}

\begin{tabular}{lll}
\hline Educated & Intellectual & Motivated \\
Quiet & Analytical & Unconventional \\
Bookish & Good & Wild \\
Intelligent & Sense of Service & Creative \\
Theoretical & Non-emotional & Survivor \\
Cerebral & Not accessible & Authoritarian \\
Smart & Environmentalist & Demanding \\
Prideful & Humorous & Handy \\
Driven & Strong & \\
Respectful of Education & Supportive of daughter's education & \\
\hline
\end{tabular}

As described in Table 1 and 2, the qualities of both the mothers and fathers strongly influenced the women deans' personalities. Specific characteristics that were common among all of the deans' mothers were homemaker, educated, extremely involved, and nurturing; and, specific characteristics that were common 
among the fathers were educated, driven, supportive of daughter's education, authoritarian, and demanding. The women deans largely attribute their selfassurance and motivation in their advancement to leadership to the support that both parents provided them growing up:

I think that having the support from my family to do whatever I wanted was really very important... When I look back across my career, a lot of the things that I accomplished, you know it wasn't that I was especially brave; I just didn't even acknowledge what the obstacles were. And you know... I just walked around obstacles because it didn't dominate my psyche and I think a lot of that was because of the supportive environment that I came up in at home.

\section{Mentor Influence}

While the deans' parents played a role in their development as an individual, their professional advancement was mainly influenced by their mentors. Although not all of the mentorship experience was positive, all of the women deans advanced out of malice for or encouragement from their mentors:

I didn't have good mentors at all. I was told verbally, "Ah, don't worry about research, it's not even important." That's what my old department head told me. Because he was just thinking totally of education, education, education .... and there's a bigger pond out there than education. But see, I was so naive... I was so used to outreach, outreach, outreach, service, service, service. Well, that's not really right; you need to have some scholarship. So, I didn't get that message. And when I went up for full professor, our new chancellor said 'Oh no, this person has not had enough scholarship' and I was denied the promotion to full professor.

While negative mentoring or lack of mentoring affected some of the women deans, others experienced positive mentoring which shaped the advancement and success of their selected profession. As one dean explained:

My major advisor encouraged me to go on for a Ph.D. And I hadn't really thought about it. He said, 'Hey, you can do this, you can do this, you'd enjoy it, you'd be good at it.' And he started giving me some leads of people that I might work with at other universities and I wound up working with the fella who had served as my advisor's advisor...it's the people who encourage you and, like my decision to go on for a Ph.D. program, it wasn't going to happen, but somebody sat down and said hey, you need to do that, and that's all it took. 


\section{Spousal Support}

The women in this study attribute their success as deans of agriculture to not only the positive influences of family members and mentors, but also the immense support they have received from their spouses. The deans' husbands have nonacademic professions which enable them to carry out household duties and support these women in their leadership role. As one dean revealed:

I don't clean the house, I rarely cook, although I'm perfectly capable of it. A lot of times I leave the house at 7:00 a.m. in the morning and don't come back till 8:30 at night, so I'm not going to prepare dinner at 8:30 at night, so he has to do a lot of those things." These women realize that their husbands' career sacrifices have been essential to their advancement in academia. "I think having a really supportive husband and a husband who is portable in his career is hugely positive." Furthermore, another dean described her husband's sacrifice as assuming the role of a stay-at-home dad. "My husband is a very introspective person, a very artsy kind of thinker, creative, a very good writer, and published in terms of poetry and literature. He didn't work, so he was home with the kids. He is just a big kid himself, loves life, loves doing things and having fun. When I was out of town, they would make pancakes and he would flip them up in the air and they would catch them on their plates and I'd find out when I came home that the spot on the ceiling was from a pancake hitting the ceiling when they were tossing it across the room."

In addition to their complimenting professions, the husbands' accommodating personalities are compatible with the driven personalities of their spouses.

We're really strong partners, really strong partners. He is protective of me, he's supportive of me, he doesn't serve as much of a critic in a sense, but he is always kind of my touch stone for what's a good idea, what's not a good idea. He's a critical asset for me. And...it's interesting, he has no college background, he has just a very little bit of college, and has worked in the trade his whole life. That kind of very practical, real, tangible relationship to the world is actually in some respects very similar to what I do. I do a lot of building too.... and it isn't necessarily with nails, but its building and he builds. And he's built a fabulous business on a business. We bring very similar kinds of values about the way we do business, a real commitment to integrity and quality work. Very frequently, people think dual career couples are two academics... we're not that way. And I think it's been a wonderful balance for the intensity of my life. And the degree to which academic communities tend to get fairly self-absorbed, often focused on some fairly small things, he's always a check on that. The 
politics and who's more important than who or who's being recognized. It's not very interesting to him... and that's helpful for me in terms of keeping my bearings.

\section{Conclusions}

Each of these women were essentially first born children which led them to develop a higher degree of achievement motivation, become linear thinkers, and establish higher expectations of themselves (Falbo, 1981). As one dean commented about her dad's high expectations as motivation to do better, she described herself as having a "linear and A-type personality." First born children also possess a stronger predisposition to leadership than later born children (Adler, 1970). In addition to being first born children, the influence of parental qualities has also impacted their success as women deans of agriculture. In a study of women university presidents, Madsen (2007) found that the mothers provided a positive role model for their daughters through strong educational backgrounds and community commitment. The women presidents described their mothers as loving, committed, and dedicated as well as influential, competent, strong, intelligent, and fun. Similarly, maternal qualities such as being a homemaker, educated, extremely involved, and nurturing were identified in this study and provided the deans with an internal drive to be fully engaged in their institutions. For example, these women have a sense of urgency to keep faculty, student, and community relations personable. As noted:

I keep in very close touch with a lot of students. They've gone on to really exciting lives and are contributing in a whole host of ways. And they still keep in touch which is really meaningful for me now that I'm in a dean role... because they still ask for advice and I still get to... track their lives and their contributions, both professional and I get to watch their personal lives. I get pictures of their kids and their new houses and...stay connected to them through the jobs they're taking and what they're trying to do. It's about passion, and it's about making a difference in the lives of students. If I took the piece away to make a difference in the lives of students from my life...my life would not be nearly as fulfilled in terms of my professional career.

Furthermore, the women presidents in Madsen's (2007) study associated characteristics such as respect, strength, high expectations, and protection with their fathers. Moreover, paternal qualities such as being educated, driven, supportive of daughter's education, authoritarian, and demanding motivated these women deans to achieve higher expectations of themselves, as well as expect more from faculty and students. As one dean stated: 
Every job I've ever taken, that's been my measure...is this the kind of job that I could spend the rest of my career doing and feel rewarded and feel like I'm making a difference and feel like I can contribute in very meaningful ways? I never want to take a job where I feel like I'm taking more than I'm giving, I never want to take a job where I don't have that passion for what I do, and I never want to take a job that I don't think I'm adequately prepared for. It's always going to be a stretch, you always have to take a stretch, you always have to take that next step, but you know inside whether you have the tools, if it's the right time for that step.

The influences of parental attributes combined with growing up during the baby boom era helped to shape and influence the development of the women deans. While the women of their mothers' generation tended to marry early and leave the workforce to raise their children and tend to household duties, their daughters achieved higher academic aspirations and pursued non-traditional career fields for women (Albers, 1999). The deans in this study obtained degrees in agricultural and extension education, agricultural engineering, animal science, biology, horticulture, and entomology. They married later than their mothers and continued working after having children (Albers, 1999). It also became more acceptable for women to contribute to the household financially and pursue professional careers, enabling them to achieve their independence. One dean described the landscape for women during this transitional time:

Now, during that period of time, there were very few females that sort of branched out of their sort of pre-determined career fields at the time, and so for a female to be in agriculture was really not an option. I don't know that there were any here to be honest with you... you live in the sort of social expectations and so that was just sort of the first group of more females entering into college...working outside the home. More and more women were working outside the home and taking on professional careers, so I was just sort of on that edge, that cutting edge of that transition period.

As compared to Madsen's (2007) study, these women deans of agriculture had mentors who recognized their gifts and talents. In addition, they also encouraged them to pursue advanced degrees and leadership positions. While some of the mentors were faculty, other mentors were involved in the women's lives outside of academics. A participant stated:

I've been very fortunate, had great mentors, my dad introduced me to a life mentor. He was in the livestock industry and had no children. He was a hard driver, and pushed people...I worked for him and he became a life 
long friend. He was just super and really, really encouraged me outside of my family because you're family's supposed to say good things and your family's supposed to encourage you, but to have somebody like that outside... He became a mentor for me when I was 9 years old and he was a mentor until he died when I was 47 . He was just a champion of people and I love him and a little piece of him is always inside of me. But that's what good mentors do and that's what I want to do for others, whether it's students or my staff or early career faculty, I want them to look back someday and say, "A little piece of is here," and that's what it's about, it's making a difference in the lives of others.

The women deans in this study relied heavily on the support and sacrifices of their spouses. Woo's (1985) research supports the notion that spousal support is crucial to women's career advancement. Similarly, in this study, the deans' husbands facilitated the women's success by taking on the day to day activities of the home and children so they could focus on their careers. In addition, spousal commitment and professional sacrifices of the deans' husbands provided opportunities for these women to pursue a leadership role in academia. Furthermore, the personalities of the deans' husbands were another contributing factor to the deans' success. The husbands assumed the role of the listener and provided an outlet for work-related frustrations of the women.

\section{Implications}

This paper offers important implications for young women in pursuit of leadership roles in academia. Women with the desire to pursue leadership need to identify a positive role model and/or mentor to encourage and foster growth in the academia profession. Without the advice, knowledge, and encouragement of a mentor, leadership advancement in academia is difficult. Furthermore, women wanting to pursue leadership roles in academia should examine spousal and family support in pursuit of their leadership goals. While both spouses may be successful in academic leadership roles, this study has shown that women who pursue leadership roles in academia acknowledge they have supportive husbands who are willing to manage the daily household activities.

\section{Recommendations and Future Research Questions}

Based on this study, several research questions have surfaced particularly related to the husbands' perceptions of their spouses' leadership role. Three questions the researchers feel should be explored are (a) How have husbands of women deans been impacted by the success of their wives pursuing a leadership role in academia? (b) How have husbands of women deans perceived their role as non- 
alpha males? and (c) How has the family been impacted by the role of their spouse or mother?

In addition to exploring the husbands' perceptions, a follow-up study should be conducted in five years with these six women deans to (a) identify their leadership advancement if applicable, (b) determine if mentorship is still a viable component of their leadership sustainability, and (c) determine whether spousal support remains an integral part of their success as a leader. 


\section{References}

Adler, A. (1970). The education of children (1930). Chicago: Regnery.

Albers, C. (1999). Sociology of families: Readings. Thousand Oaks, California: Pine Forge Press.

Association of Public and Land-grant Universities (2009). Dean and directors of academic programs in schools and colleges of agriculture, agriculture and life sciences, or agriculture and natural resources. Retrieved from www.aplu.org/NetCommunity/Document.Doc?id=1645

Astin, H. S., \& Leland, C. (1991). Women of influence, women of vision. San Francisco: Jossey-Bass.

Auster, C., \& Auster, D. (1981). Factors influencing women's choice of nontraditional careers: The role of family, peers, and counselors. Vocational Guidance Quarterly, 29(3), 253-263.

Bennis, W. (1989). On becoming a leader. Reading, MA: Addison-Wesley Publishing Company.

Bogdan, R., \& Biklen, S. (2007). Qualitative research for education: An introduction to theories and methods. Boston: Pearson Education.

Creswell, J. (2007). Qualitative inquiry \& research design: Choosing among the five approaches. Thousand Oaks, CA: Sage Publications.

Cooke, L. H. (2004). Finding the self who leads: From one woman's perspective. Unpublished Ph.D. dissertation, The University of North Carolina, Greensboro.

Cubillo, L., \& Brown, M. (2003). Women into educational leadership and management: international differences? Journal of Educational Administration, 41(3), 278-291.

Eagly, A. H., \& Carli, L. L. (2004). Women and Men as Leaders. In J. Antonakis, A. T. Cianciolo, \& R. J. Sternberg (Eds.), The nature of leadership, (pp. 279-301). Thousand Oaks, California: Sage Publications.

Eagly, A. H., Johannesen-Schmidt, M. C., \& van Engen, M. (2003). Transformational, transactional, and laissez-faire leadership styles: A 
meta-analysis comparing women and men. Psychological Bulletin, 95, 569-591.

Ernst, C., \& Angst, J. (1983). Birth order: Its influence on personality. Berlin: Springer Veriag.

Falbo, T. (1981). Relationships between birth category, achievement, and interpersonal orientation. Journal of Personality and Social Psychology, 41(1), 121-131.

Food and Agriculture Organization of the United Nations (1998). Issues in urban agriculture. Spotlight magazine. Retrieved from http://www.fao.org.

Hartman, M. S. (Ed.) (1999). Talking leadership: Conversations with powerful women. New Brunswick: Rutgers University Press.

Hennig, M., \& Jardim, A. (1977). The managerial woman. Garden City, NY: Anchor Press/Doubleday.

Keown, C. F., \& Keown, A. L. (1982). Success factors for corporate woman executives. Group \& Organizational Studies, 7(4), 445-456.

Lorenzen, Z. (1996). Female leadership: Some personal and professional reflections. Leadership \& Organization Development Journal. Copenhagen, Denmark: MCB University Press, 17(6), 24-31.

Madsen, S. R. (2010). Chinese Women Administrators in Higher Education: Developing Leadership Throughout Life. Academic Leadership Online Journal, 8(2), 1-9.

Madsen, S. R. (2007). Women university presidents: Career paths and educational backgrounds. Academic Leadership Online Journal, 5(1), 1-3.

Madsen, S. R. (2006). Learning to Lead in Higher Education: Insights into the Family Backgrounds of Women University Presidents. The Journal of Women in Educational Leadership, 5(3), 183-200.

Matz, S. I. (2002). Women leaders: Their styles, confidence, and influences. The Claremont Graduate University. Unpublished Dissertation.

McDonald, I. (2004). Women in management: an historical perspective. Employee Relations, 26(3), 307-319. 
Rubin, B. D. (2004). Pursuing excellence in higher education: Eight fundamental challenges. San Francisco: Jossey-Bass.

Sulloway, F. J. (1996). Born to rebel. New York: Parthenon Books.

Van Velsor, E., \& Hughes, M. W. (1990). Gender differences in the development of managers: How women managers learn from experience. Center for Creative Leadership, Greensboro, NC. ED 334511.

Wells, S. J. (1998). Women entrepreneurs: Developing leadership for success. New York: Garland Publishing.

Woo, L. C. (1985). Women administrators: Profiles of success. The Phi Delta Kappan, 67(4), 285-288.

Wright, H. K. (2002/3). Qualitative research in education: From an attractive nuisance to a dizzying array of traditions and possibilities. In Tennessee Education 32 (2)/33(1), pp. 7-15. 


\section{Author Biographies}

Sarah Kleihauer graduated from the University of Tennessee, Knoxville with a Master's of Science in Agricultural and Extension Education. Sarah is currently teaching agricultural education at Wilson Central High School in Lebanon, Tennessee. Sarah is actively involved in the FFA and the Tennessee Association of Agricultural Educators.

Carrie Stephens is an Associate Professor in the Agricultural Leadership, Education and Communications Department at the University of Tennessee. She is active in the Association of Leadership Educators, American Association of Agricultural Educators, Tennessee Association of Agricultural Educators, and American Association of Supervision and Curriculum Development. She actively serves in leadership roles in the Knoxville community. Carrie has published articles in the Journal of Leadership Education, Journal of Agricultural Education, North American Colleges and Teachers Association Journal, and coauthored a book chapter. Carrie enjoys teaching and conducting research in the areas of teaching, learning, and supervisory leadership.

William E. Hart is an Associate Professor in the Biosystems Engineering and Soil Science Department at the University of Tennessee, Knoxville. He is active member of the American Society of Agricultural and Biological Engineers. He has published articles primarily in ASABE Journals, Applied Engineering in Agriculture and Transactions of the ASABE. He teaches courses in the Biosystems Engineering Technology curriculum and his areas of research include machinery systems, agricultural chemical application technology, and precision agriculture. 